\title{
Effect of Leek (A. ampeloprasum L.) and Scallion (A. chinense L.) on Breadmaking Properties
}

\author{
Masaharu SeguchI ${ }^{1}$ and Makoto $\mathrm{ABE}^{2}$ \\ ${ }^{I}$ Faculty of Home Economics, Laboratory of Food Technology, Kobe Women's University, Suma-Ku, Kobe City, 654-8585 Japan \\ ${ }^{2}$ Faculty of Intercultural Studies, Dept. of Japanese Studies, Gakushuin Women's College, Tokyo, 162-8650 Japan
}

Received July 5, 2004; Accepted October 20, 2004

\begin{abstract}
Allium such as leek (A. ampeloprasum L.) and scallion (A. chinense L.) powders blended with wheat flour improved the breadmaking properties of bread height $(\mathrm{mm})$ and specific volume $\left(\mathrm{cm}^{3} / \mathrm{g}\right)$. Brabender farinographs of the Allium (leek and scallion) powder/wheat flour showed remarkable changes in the profile such as width of the tail. Size-exclusion high performance liquid chromatography (SE-HPLC) of the wheat proteins in the Allium (leek and scallion) blended or not blended wheat flour showed a profile of low, medium and high molecular weight peaks. The area of the high molecular weight peak of the wheat proteins was larger in the Allium blended flours than in control (wheat flour) indicating that these protein fractions were related to the improvement in breadmaking properties.
\end{abstract}

Keywords: breadmaking, leek, scallion

\section{Introduction}

Seguchi and Abe (2003) reported that breadmaking properties of bread height $(\mathrm{mm})$ and specific volume $\left(\mathrm{cm}^{3} / \mathrm{g}\right)$ were improved by blending $1.0 \%$ of welsh onion (A. fistulosum L.) powder in wheat flour. Allium such as welsh onion (A. fistulosum L.), leek (A. ampeloprasum L.) and scallion (A. chinense L.) is known to have many medicinal properties: antibiotic action, lowering of blood glucose and plasma cholesterol levels, antihyperlipidemia, thrombolysis, anti-platelet aggregation, prevention of rheumatic arthritis, and diuretic effects (Whitaker 1976). Allium is known to contain characteristic volatiles which are produced enzymatically when tissue is injured. Substrates for the production of these volatiles are known to be alkyl cysteine sulfoxides, and are derivatives of the amino acid cysteine. These derivatives give rise through several reactions to the sulfur-containing volatiles of disulfides. These disulfides act as redox agents in dough, and improve the breadmaking properties (Seguchi and Abe 2003 and 2004). It was reported that dimethyl disulfide $\left(\mathrm{Me}_{2} \mathrm{~S}_{2}\right)$ is enzymatically produced in leek and scallion (Saghir and others 1964). From these results it can be assumed that leek and scallion containing $\mathrm{Me}_{2} \mathrm{~S}_{2}$ may have important effects on the improvement of breadmaking properties (bread height and specific volume) through disulfide formation of gluten protein molecules occurring by oxidation with $\mathrm{Me}_{2} \mathrm{~S}_{2}$. In this paper we used leek and scallion powder/wheat flour in breadmaking tests, and investigated whether we could obtain breads having property characteristics good for human health.

\section{Materials and Methods}

Wheat flour, leek, scallion and reagents Four dif-

E-mail: seguchi@suma.kobe-wu.ac.jp ferent wheat flours were used in this experiment; Red Knight (Nitto Flour Milling Co., Ltd., Tokyo, Japan), Super King and Kameria (Nisshin Flour Milling Co., Ltd., Tokyo), and Haruyutaka (Ebetsu Flour Milling Co., Ltd., Hokkaido, Japan). Protein conversion was $\mathrm{N} \times 5.7$. Ash was determined by the AACC method $(08-01,1995)$ at $14.0 \%$ m.b. The leeks and scallions were farm-cultivated (Yahiro Sangyo Co., in Gifu, Japan), and powders were prepared using a vacuum dehydrator with a balance chamber drying system (Yahiro Sangyo). Analytical data of the leek and scallion powder were protein 30.4 and $3.85 \%$, ash 14.5 and $2.32 \%$, and moisture 17.5 and $7.5 \%$, respectively.

Brabender farinograph and breadmaking test Leek and scallion powders were blended with wheat flour; the substitution levels of the leek and scallion powders were $0.25,0.50,0.75$ and $1.00 \%$, and 1.00, 3.00, 5.00 and $7.00 \%$, respectively. Baking absorption of each blended flour was determined in a farinograph with $300 \mathrm{~g}$ of flour (AACC method 54-21, 1995). Breadmaking was performed according to Seguchi et al. (1997). Flour (290 g), compressed yeast $(8.7 \mathrm{~g})$, sugar $(14.5 \mathrm{~g})$, salt $(2.9 \mathrm{~g})$, and water (estimated from a farinograph at 500BU) were mixed in a computer-controlled National Automatic Bread Maker (SDBT6, Matsushita Electric Ind. Co., Ltd., Japan) with the first proof for $2 \mathrm{hr} 20 \mathrm{~min}$ at $30^{\circ} \mathrm{C}$. The time was $15 \mathrm{~min}$ for the first mixing, $50 \mathrm{~min}$ of rest, $5 \mathrm{~min}$ for the second mixing, and $70 \mathrm{~min}$ of fermentation. Mixing action (time and temperature) was all carefully computer-controlled in the Bread Maker. The dough was then taken out of from the Bread Maker and divided into $120 \mathrm{~g}$ pieces, rounded, molded, and placed in baking pans (AACC method 10$10 \mathrm{~A}, 1995)$. The dough was further proofed for $22 \mathrm{~min}$ at $38^{\circ} \mathrm{C}$, and was baked at $210^{\circ} \mathrm{C}$ for $30 \mathrm{~min}$ in a model $\mathrm{DN}$ 63 deck style oven (Yamato Scientific Co., Ltd., Japan). After baking, the bread was removed from the pan and 
cooled for $1 \mathrm{hr}$ at a room temperature of $26^{\circ} \mathrm{C}$ and relative humidity of $43 \%$. Bread height $(\mathrm{mm})$, weight $(\mathrm{g})$, and volume $\left(\mathrm{cm}^{3}\right)$ were measured, and the crumb grains were evaluated visually.

Size-exclusion high-performance liquid chromatography (SE-HPLC) of proteins from those flours Leek $(0.5 \%)$ and scallion $(5.0 \%)$ powders were blended with wheat flour, respectively. Blended flour (300 g) mixed with $202 \mathrm{ml}$ water was subjected to a farinograph test for $30 \mathrm{~min}$ at $30^{\circ} \mathrm{C}$ and was freeze dried. Freeze dried powder $(5.0 \mathrm{~g})$ was suspended in $50 \mathrm{ml}$ of $1 \%$ SDS (sodium dodecyl sulfate) solution and shaken overnight. Extracted proteins were dialyzed against water and freeze dried. Size-exclusion high-performance liquid chromatography (SE-HPLC) of proteins from those flours was performed according to Seguchi et al. (2001). For SE-HPLC analysis at $280 \mathrm{~nm}$, a Shimadzu liquid chromatograph LC-3A connected to a Shodex Protein KW 803 column (5009010) was used.

Statistical Analysis A statistical software package (SPSS Inc., Chicago, IL.) was used for the statistical analyses. Four loaves of bread were baked for each treatment and bread height $(\mathrm{mm})$ and specific volume $\left(\mathrm{cm}^{3} / \mathrm{g}\right)$ were measured 4 times for each sample and averaged. They were replicated in the analyses from one set of breads. Analysis produced significant $F$ values by analysis of variance, followed by Duncan's multiple range test for comparison of mean.

\section{Results and Discussion}

Effect of Allium (leek and scallion) powders on breadmaking properties Analytical data of Red Knight, Super King and Kameria, and Haruyutaka wheat flours are indicated in Table 1. Leek and scallion were dried by freeze drying method, and used in breadmaking. The effect of the leek and scallion powder on breadmaking properties (bread

Table 1. Protein and ash contents (\%) of wheat flour ${ }^{\mathrm{a}}$.

\begin{tabular}{llc}
\hline \multicolumn{1}{c}{ Flour } & Protein $^{\mathrm{b}}$ & Ash \\
\hline Red Knight & $14.8(0.3)$ & $0.37(0.00)$ \\
Super King & $16.1(0.2)$ & $0.43(0.03)$ \\
Kameria & $13.6(0.3)$ & $0.40(0.02)$ \\
Haruyutaka & $11.5(0.1)$ & $0.40(0.00)$ \\
\hline
\end{tabular}

${ }^{a}$ Based on dry basis.

${ }^{a}$ Values represent average and standard deviation in parenthesis of duplicates.

b $\mathrm{N} \times 5.7$ height $(\mathrm{mm})$ and specific volume $\left.\left(\mathrm{cm}^{3} / \mathrm{g}\right)\right)$ are indicated, respectively, in Table 2 and Figure 1. When $0.50 \%$ of the leek powder was blended with Red Knight, Kameria, and Haruyutaka wheat flour, maximum bread height ( $\mathrm{mm}$ ) and specific volume $\left(\mathrm{cm}^{3} / \mathrm{g}\right)$ were obtained. And when $5.00 \%$ of the scallion powder was blended with Red Knight, Super King and Kameria wheat flour, respectively, same maximum values were obtained. When more than these percentages of the leek and scallion powders were blended, the breadmaking properties of bread height and specific volume decreased, respectively. Loaf shape and interior grain are indicated in Figure 1, which shows the change in these factors. With increase in the percent of leek to wheat flour, the color of resulting bread crumbs changed to deep green, although in the case of scallion powder the color of crumbs did not change. From these results, it was concluded that leek and scallion are remarkably related to the improvements in breadmaking properties. Seguchi and Abe (2003) reported that welsh onion powder (1.0\%) blended wheat flour could improve the breadmaking properties of bread height $(\mathrm{mm})$ and specific volume $\left(\mathrm{cm}^{3} / \mathrm{g}\right)$; reagent $\mathrm{Pro}_{2} \mathrm{~S}_{2}$ (dipropyl disulfide) which is known to be contained in welsh onion also improved breadmaking properties, and they concluded that these baking results blended with welsh onion were due to the $\mathrm{Pro}_{2} \mathrm{~S}_{2}$ it contained. It is known that leek and scallion powders contain $\mathrm{Me}_{2} \mathrm{~S}_{2}$ (Saghir and others, 1964), which was shown to improve breadmaking properties after mixing with wheat flour (Seguchi and Abe, 2004). Those results indicated that the improvement of the properties by leek or scallion would

$\mathrm{L}$

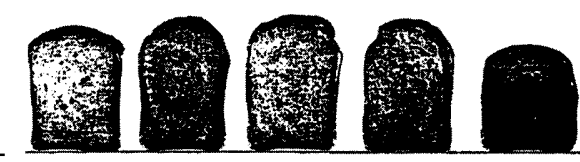

$\mathrm{S}$

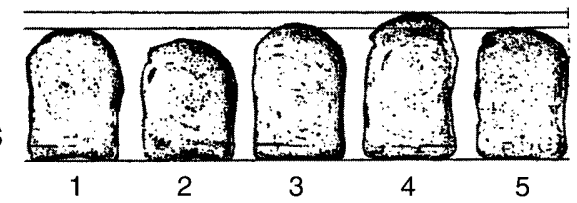

Fig. 1. The appearance of sectioned bread baked from leek (L) and scallion (S) powder/Red Knight wheat flour. From left to right $0.00(1)$, $0.25(2) .0 .50(3), 0.75(4)$ and $1.00 \%(5)$ leek, and $0.00(1), 1.00(2), 3.00(3)$, $5.00(4)$ and $7.00 \%(5)$ scallion were blended with Red Knight wheat flour.

Table 2. Effect of Allium (leek and scallion powders) on breadmaking properties.

\begin{tabular}{|c|c|c|c|c|c|c|c|c|c|c|c|c|c|}
\hline \multirow[b]{2}{*}{$\begin{array}{l}\text { Leek } \\
(\%)\end{array}$} & \multicolumn{2}{|c|}{ Red Knight } & \multicolumn{2}{|c|}{ Kameria } & \multicolumn{2}{|c|}{ Haruyutaka } & \multirow[b]{2}{*}{ Scallion } & \multicolumn{2}{|c|}{ Red Knight } & \multicolumn{2}{|c|}{ Super King } & \multicolumn{2}{|c|}{ Kameria } \\
\hline & $\begin{array}{l}\text { Height } \\
(\mathrm{mm})\end{array}$ & $\begin{array}{l}\text { Specific } \\
\text { volume } \\
\left(\mathrm{cm}^{3} / \mathrm{g}\right)\end{array}$ & $\begin{array}{l}\text { Height } \\
(\mathrm{mm})\end{array}$ & $\begin{array}{l}\text { Specific } \\
\text { volume } \\
\left(\mathrm{cm}^{3} / \mathrm{g}\right)\end{array}$ & $\begin{array}{l}\text { Height } \\
(\mathrm{mm})\end{array}$ & $\begin{array}{l}\text { Specific } \\
\text { volume } \\
\left(\mathrm{cm}^{3} / \mathrm{g}\right)\end{array}$ & & $\begin{array}{l}\text { Height } \\
\text { (mm) }\end{array}$ & $\begin{array}{l}\text { Specific } \\
\text { volume } \\
\left(\mathrm{cm}^{3} / \mathrm{g}\right)\end{array}$ & $\begin{array}{l}\text { Height } \\
(\mathrm{mm})\end{array}$ & $\begin{array}{l}\text { Specific } \\
\text { volume } \\
\left(\mathrm{cm}^{3} / \mathrm{g}\right)\end{array}$ & $\begin{array}{l}\text { Height } \\
(\mathrm{mm})\end{array}$ & $\begin{array}{l}\text { Specific } \\
\text { volume } \\
\left(\mathrm{cm}^{3} / \mathrm{g}\right)\end{array}$ \\
\hline 0.00 & $69.8 \mathrm{a}(1.8)$ & $3.29 \mathrm{a}(0.71)$ & $71.3 \mathrm{a}(0.8)$ & $3.14 \mathrm{a}(0.07)$ & $69.4 \mathrm{a}(3.5)$ & $3.45 \mathrm{a}(0.06)$ & 0.00 & $71.5 \mathrm{a}(1.4)$ & $3.42 \mathrm{a}(0.05)$ & $83.3 \mathrm{a}(2.3)$ & $4.34 \mathrm{a}(0.12)$ & $77.9 \mathrm{a}(0.5)$ & $3.91 \mathrm{a}(0.03)$ \\
\hline 0.25 & $71.3 \mathrm{a}(1.6)$ & $3.53 \mathrm{a}(0.32)$ & $72.3 b(1.6)$ & $3.39 b(0.13)$ & $73.7 \mathrm{~b}(10)$ & $3.49 \mathrm{a}(0.04)$ & 1.00 & $67.7 b(2.4)$ & $3.21 \mathrm{~b}(0.12)$ & $78.6 \mathrm{~b}(2.4)$ & $4.16 \mathrm{a}(0.16)$ & $70.0 \mathrm{~b}(1.8)$ & $3.42 \mathrm{~b}(0.10)$ \\
\hline 0.50 & $78.4 b(3.6)$ & $3.78 \mathrm{~b}(0.02)$ & $78.5 c(2.2)$ & $3.62 c(0.15)$ & $75.1 \mathrm{c}(1.5)$ & $3.87 b(0.07)$ & 3.00 & $68.2 b(1.7)$ & $3.18 \mathrm{~b}(0.04)$ & $85.2 \mathrm{a}(2.2)$ & $4.26 \mathrm{a}(0.22)$ & $80.2 \mathrm{c}(0.4)$ & $4.00 \mathrm{a}(0.08)$ \\
\hline 0.75 & $75.4 \mathrm{c}(2.4)$ & $3.44 \mathrm{a}(0.09)$ & $78.4 \mathrm{~d}(1.5)$ & $3.41 \mathrm{~d}(0.08)$ & $72.2 \mathrm{~d}(3.6)$ & $3.56 \mathrm{c}(0.09)$ & 5.00 & $78.6 \mathrm{c}(1.9)$ & $3.69 \mathrm{c}(0.15)$ & $87.9 \mathrm{c}(4.7)$ & $4.72 \mathrm{~b}(0.05)$ & $83.2 \mathrm{~d}(2.2)$ & $4.36 \mathrm{c}(0.10)$ \\
\hline 1.00 & $60.2 \mathrm{~d}(4.7)$ & $2.93 \mathrm{c}(0.22)$ & $71.0 \mathrm{a}(1.4)$ & $2.92 \mathrm{e}(0.04)$ & $70.0 \mathrm{a}(1.7)$ & $3.04 \mathrm{~d}(0.09)$ & 7.00 & $68.6 b(2.7)$ & $3.27 \mathrm{~d}(0.04)$ & $83.6 \mathrm{a}(0.8)$ & $4.34 \mathrm{a}(0.01)$ & $76.9 \mathrm{a}(1.8)$ & $3.87 \mathrm{a}(0.06)$ \\
\hline
\end{tabular}

Values respresent means of 4 replicates with the standard deviation in parenthesis. Means followed by different letters in the columns are significantly different at $p=0.05$, according to Duncan's multiple range test 
be due to the $\mathrm{Me}_{2} \mathrm{~S}_{2}$ content through disulfide formation. Brabender farinograph and SE-HPLC profiles of Allium (leek and scallion) powder/wheat flour In wheat flour the BU value is almost constant for $30 \mathrm{~min}$ (Fig. 2A), and the width of the tail is also the same. However, when $0.50 \%$ of leek powder was blended with the wheat flour (Fig. 2-B), the width of the tail after $30 \mathrm{~min}$ became narrower. Some different mixing behaviors occurred when the peak mixing time was modified (arrow) and the BU value, that is, the retardation of mixing time and decrease of BU value were observed. These changes may be related to actual breadmaking values. Scallion/wheat flour also showed the same results (data not shown here). Seguchi and Abe (2004) reported that the blend of $6.3 \mathrm{mg} \% \mathrm{Me}_{2} \mathrm{~S}_{2}$ first caused retardation of the peak mixing time and increase in the $\mathrm{BU}$ value, and afterward the BU value gradually decreased with a decrease in the width of the tail. The tail

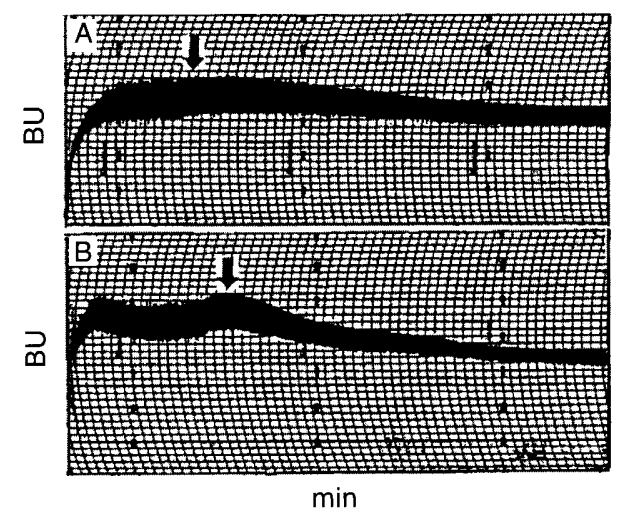

Fig. 2. Effects of leek on Brabender Farinogram profiles of Red Knight wheat flour. From top to bottom; Red Knight wheat flour (A) and $0.50 \%$ leek/Red Knight wheat flour (B). Arrow shows peak times.

width finally lowered to $1 / 5$ of the original value.

For further investigation, proteins from the flour dough were extracted with $1 \%$ SDS (sodium dodecyl sulfate) and subjected to SE-HPLC. Figure 3-1-A, B and C indicates the SE-HPLC profiles of $1 \%$ SDS-extracted wheat proteins. The column was equilibrated with $1 \%$ SDS, and the proteins were eluted from the column with $1 \%$ SDS. As previously reported (Seguchi et al., 2001), three main protein peaks, H (High) MW I, M (Medium) MW II, and L (Low) MW III appeared and in flour the peak heights were almost the same (Fig. 3-1-A and Table 3). However, the HPLC profile, in which the proteins were extracted from $0.50 \%$ leek and $5.00 \%$ scallion/wheat flour, respectively, shows that the areas of the peaks changed: HMW I became larger and the others became smaller than proteins extracted from wheat flour (Fig. 3-1-B and -C), which suggests that MMW II and LMW III proteins are rearranged by leek and scallion, respectively, and changed to HMW I proteins. The SDSextracted wheat flour proteins and the SDS-extracted proteins from leek and scallion/wheat flour, respectively, were reduced in 1\% 2-mercaptoethanol and eluted with the same $1 \%$ SDS solution containing 1\% 2-mercaptoethanol from the SE-HPLC column. All elution profiles of the proteins from flours with or without leek and scallion
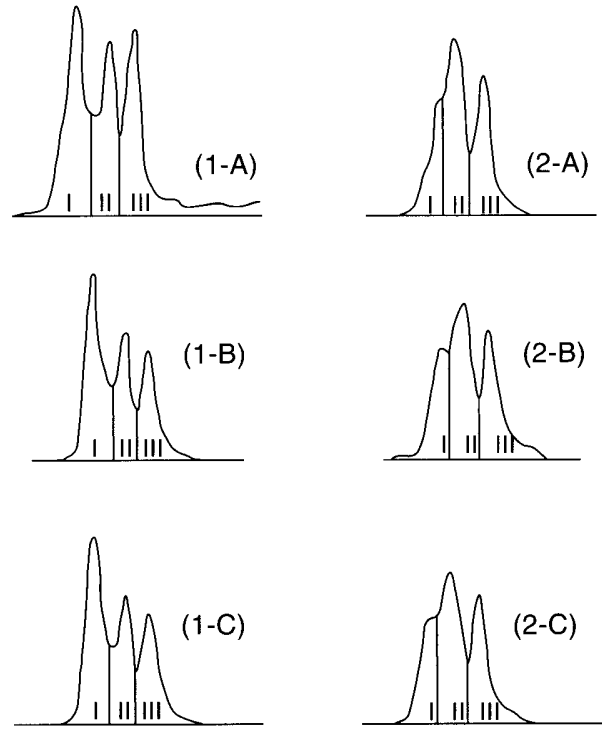

Fig. 3. Size-exclusion high-performance liquid chromatogram (SEHPLC) profiles of proteins extracted from Red Knight wheat flour (A), $0.50 \%$ leek/Red Knight wheat flour (B), and $5.00 \%$ scallion/Red Knight wheat flour $(\mathrm{C})$. Proteins $(1.0 \mathrm{mg}$ ) were dissolved in $1.0 \mathrm{ml}$ of $1.0 \%$ sodium dodecyl sulfate (SDS) and eluted from a column with the same solution $(1-\mathrm{A}, \mathrm{B}$, and $\mathrm{C})$, and proteins were reduced by boiling $(5 \mathrm{~min})$ in $1 \%$ SDS containing $1 \% 2$-mercaptoethanol and eluted with the same solution (2-A, B, and C)

Table 3. Effect of leek and scallion on the ratio of HMW I. MMW II and LMW III protein (\%) in HPLC profile (1\% SDS).

\begin{tabular}{lccc}
\hline Wheat flour & $\begin{array}{c}\text { Wheat flour } \\
+0.50 \% \text { leek } \\
(\%)\end{array}$ & $\begin{array}{c}\text { Wheat flour } \\
+5.00 \% \text { scallion } \\
(\%)\end{array}$ \\
\hline HMW I & $36.7 \mathrm{a}$ & $44.6 \mathrm{a}$ & $43.9 \mathrm{a}$ \\
MMW II & $28.3 \mathrm{a}$ & $28.5 \mathrm{~b}$ & $25.5 \mathrm{~b}$ \\
LMW III & $35.0 \mathrm{a}$ & $27.6 \mathrm{c}$ & $30.5 \mathrm{c}$ \\
\hline
\end{tabular}

Values represent means of 4 replicates with the standard deviation in parenthesis.

Means followed by different letters in the columns are significantly different at $p=0.05$, according to Duncan's multiple range test.

(Fig. 3-2-A, B and C) were almost the same. This shows that the increase in the area of the HMW I proteins by blending with leek and scallion, respectively, in the $1 \%$ SDS eluted column profile may possibly be caused by the rearrangement of dough proteins by disulfide. Table 3 shows data of the areas of HMW I, MMW II and LMW III, in which the area of HMW I in flour increased from $36.7 \%$ to $44.6 \%$ when blended with $0.50 \%$, and increased from $36.7 \%$ to $43.9 \%$ when blended with $5.00 \%$ scallion.

\section{Conclusions}

Improvements of breadmaking properties such as bread height $(\mathrm{mm})$ and specific volume $\left(\mathrm{cm}^{3} / \mathrm{g}\right)$ could be observed by the blending of leek (A. ampeloprasum L.) and scallion (A. chinense L.) powders in wheat flour, respectively. Brabender farinograph profiles suggested that the Allium (leek and scallion) changed the wheat proteins, and sizeexclusion high performance liquid chromatography (SEHPLC) of the wheat proteins indicated that the increase of high molecular weight wheat proteins due to oxidation by the Allium was strongly related to the improvements of 
the breadmaking properties. Allium is known to have beneficial effects on health, so we were able to obtain breads having a good breadmaking property characteristics for human health.

\section{References}

AACC. (1995). Approved Methods of the AACC. 9th ed. Method 08-01, approved April 1961, revised October 1981 and October 1986; Method 10-10A; Method 54-21, approved April 1961, revised October 1994, final approval November 1995.: St. Paul, Minn.: AACC.

Saghir, A.R., Mann, L.K., Bernhard, R.A. and Jagobsen, J.V. (1964).
Am. Soc. Horticult. Sci., 84, 386-398.

Seguchi, M., Hayashi, M. and Matsumoto, H. (1997). Effect of gaseous acetic acid on dough rheological and breadmaking properties. Cereal Chem., 74, 129-134.

Seguchi, M., Morimoto, N., Abe, M. and Yoshino, Y. (2001). Effect of Maitake (Grifola frondosa) Mushroom Powder on Bread Properties. J. Food Sci., 66, 261-264.

Seguchi, M. and Abe, M. (2003). Effect of Welsh onion (Allium fistulosum L.) on breadmaking properties. J. Food Sci., 68, 1810-1813.

Seguchi, M. and Abe, M. (2004). Effect of disulfides on breadmaking properties. Cereal Chem. Accepted.

Whitaker, J.R. (1976). Adv. in Food Research, Vol. 22 (Chichester, CO. et al, eds) 73, Academic Press, New York. 